УДК 373.5.016:811.161.2 (075.3)*5-11

DOI: https://doi.org/10.54662/veresen.2.2021.07

\author{
Анастасія Кузнєцова, \\ ORCID iD 0000-0002-5947-0387 \\ старший викладач кафедри \\ теорії й методики мовно-літературної \\ та художньо-естетичної освіти \\ Миколаӥвський обласний інститут \\ післядипломної педагогічної освіти \\ Адміральська, 4-а, м. Миколаїв, 54001, Україна \\ anastasiia.kuznietsova@moippo.mk.ua
}

\title{
ВИВЧЕННЯ СИНТАКСИСУ НА МАТЕРІАЛІ ТВОРЧОСТІ ЛЕСІ УКРАЇНКИ
}

У практико орієнтованій статті проаналізовано проблему використання літературної спадщчин відомої української письменниці й громадської діячки ХХ століття Лесі Українки на сучасному урочі української мови. Визначено дидактичний потенціал програмових творів письменниці - навчальні, розвивальні й виховні функиї текстів у процесі вивчення синтаксису. Розроблено оригінальні вправи на основі поезій Лесі Украӥнки під час опрачювання простого речення в середній школі. Запропоновано систему завдань за тексточентричним підходом для вивчення складного речення в старшій школі.

Ключові слова: вивчення синтаксису; лінгводидактичний аналіз тексту; поетичні тексти Лесі Українки; просте речення; складне речення; текстоцентризм.

(C) Кузнєцова А. М., 2021

Вступ. Щороку вшановуємо пам'ять Лесі Українки - видатної дочки нашого народу, талановитої письменниці, перекладачки, громадської діячки й фольклористки, однієї з найупливовіших жінок давньої i сучасної України. Її внесок у культурне життя, зокрема літературне, неоціненний, адже мисткиня представила різні жанри лірики, епосу, драми; розвинула жанр драматичної поеми в українській літературі. Така багатогранність таланту Лесі Українки пояснює значний інтерес до вивчення іiї творчості як у художньому, так і методичному аспектах.

Питанню характеристики мовних особливостей літературної спадщини Лесі Українки присвячено наукові розвідки М. І. Пелипась (Пелипась М. І., 2017), Т. Є. Масицької та I. А. Мельник (Масицька Т. С., Мельник I. А., 2020). Чимало дослідників розкрили особливості побудови уроку української мови 3 використанням міжпредметних зв'язків (українська література, мистецтво) в початковій школі. I. М. Лютко (Лютко I. М., 2019) і Н. Т. Новосельська (Новосельська Н. Т., 2018) визначили інтегрований урок української мови і літературного читання як продуктивне заняття для розвитку ключових і предметних компетентностей сучасних здобувачів освіти.

Розробки О. П. Фучили (Фучила О. П., 2015) і Г. В. Грибан (Грибан Г. В., 2001) містять окремі практичні завдання 3 використанням поезій Лесі Українки на уроці рідної (української) мови під час опрацювання морфології, орфографії, морфеміки і словотвору, синтаксису складного речення.

Мало дослідженим залишається питання вивчення синтаксису в середній i старшій школі на текстоцентричній основі, розроблення комплексних вправ.

Постановка завдання. Метою науково-методичної статті є лінгводидактичний аналіз поетичних текстів Лесі Українки на 
сучасному уроці української мови.

Для реалізації мети визначені такі завдання:

1. 3'ясувати дидактичний потенціал програмових творів письменниці:

2. Розробити оригінальні вправи на основі поетичних текстів Лесі Українки під час вивчення синтаксису в середній школі:

3. Запропонувати систему завдань за текстоцентричним підходом для опрацювання складного речення в старшій школі.

Виклад основного матеріалу дослідження. Літературна спадщина Лесі Українки - це джерело художньо-естетичної насолоди, позаяк мова іiі творів жива, органічна, представлена багатим лексико-граматичним матеріалом, яскравими виражальними засобами, авторськими новотворами. Недаремно М. I. Пелипась, цитуючи поета М. Т. Рильського, уважав мову Лесі Українки однією з найбагатших в українській літературі, такою, що могла би стати предметом вагомого наукового дослідження (Пелипась М. І., 2017, с. 70).

На окрему увагу заслуговує синтаксичне розмаїття художніх текстів мисткині: різні види речень за метою висловлювання, емоційним забарвленням, будовою, повнотою поданої інформації. Чимало поезій авторки містять речення, ускладнені звертаннями, однорідними членами, вставними конструкціями, відокремленими членами речення. Широко представлені й усі види складного речення: складносурядні, складнопідрядні, безсполучникові, складні речення з кількома підрядними, складні синтаксичні конструкції - окремо і навіть у рамках одного твору. Саме тому художні тексти Лесі Українки варто використовувати в процесі вивчення різних синтаксичних одиниць у середній і старшій школі.

У шкільному курсі української мови синтаксис опановують у 5, 8, 9, 10, 11 клаcax (Українська мова. Програма, 2017), а творчість Лесі Українки - у 6, 8, 10 класах (Українська література. Програма, 2017). Докладно теми й конкретні назви творів представлено в таблиці 1 (с.67).

Bересень № 2 (89) 2021
Очевидно, шкільний курс передбачає одночасне вивчення синтаксису й творчості Лесі України у 8 й 10 класах. В інших це спонукатиме вчителів будувати урок української мови на основі повторення вивченого матеріалу або ж працювати на випередження, зацікавлюючи в такий спосіб творчістю письменниці.

Пропонуємо добірку авторських вправ і завдань, що ілюструють дидактичні можливості поетичних творів Лесі Українки під час вивчення синтаксису в середній і старшій школі. Спираючись на класифікацію О. П. Глазової (Глазова О. П., 2013), представляємо різні типи вправ на основі тексту художнього твору:

- аналітичні - визначення граматичних особливостей мовних одиниць у тексті;

- конструктивні - перебудова тексту або його фрагментів;

- творчі - домислення частини або створення власного тексту.

\section{Вправа 1.}

Тема. Поділ зв'язного висловлення (тексту) на речення. Інтонація речень, різних за метою висловлення. Розділові знаки в кінці речення (5 клас).

-Прочитайте уважно запропонований текст.

Поблискують черешеньки в листі зелененькім черешеньки ваблять очі діточкам маленьким дівчаточко й хлоп'яточко під деревцем скачуть простягають рученята та мало не плачуть раді б вишню з '̈сти та високо лізти ой раді б зірвати ma годi дістати (Леся Українка, 2021, c. 261).

-Чи знайомий він вам? Хто автор? Яка назва твору?

-Поділіть зв'язне висловлення на речення. Поставте необхідні розділові знаки.

- Які можливі варіанти?

-Визначте види речень за метою висловлювання. Прочитайте виразно, дотримуючись відповідної інтонації.

-Поясніть розділові знаки в кінці речень.

\section{Вправа 2.}

Тема. Словосполучення. Відмінність 
Таблиия 1.

Програмові теми із синтаксису й програмові твори Лесі Українки (складено автором самостійно)

\begin{tabular}{|c|c|c|}
\hline Клас & $\begin{array}{c}\text { Українська мова, } \\
\text { програмові теми із синтаксису }\end{array}$ & $\begin{array}{c}\text { Українська } \\
\text { література, програмові } \\
\text { твори Лесі Українки }\end{array}$ \\
\hline 5 & $\begin{array}{c}\text { Повторення вивченого в початкових класах. Текст. } \\
\text { Речення. Відомості із синтаксису й пунктуації. } \\
\text { Словосполучення. Речення, його граматична основа. } \\
\text { Другорядні члени речення. Речення з однорідними } \\
\text { членами. Звертання. Вставні слова і сполучення слів. } \\
\text { Складні речення з безсполучниковим і сполучниковим } \\
\text { зв'язком. Пряма мова. Діалог }\end{array}$ & - \\
\hline 6 & $\begin{array}{c}\text { Повторення, узагальнення й поглиблення вивченого } \\
\text { (на початку року) }\end{array}$ & $\begin{array}{c}\text { «Мрії», «Як дитиною, } \\
\text { бувало...», «Тиша } \\
\text { морська» }\end{array}$ \\
\hline 7 & $\begin{array}{c}\text { Повторення та узагальнення вивченого. Розділові } \\
\text { знаки у вивчених синтаксичних конструкціях }\end{array}$ & - \\
\hline 8 & $\begin{array}{c}\text { Синтаксис. Пунктуація. Словосполучення й речення. } \\
\text { Просте речення. Члени речення. Односкладне речення. } \\
\text { Односкладні прості речення. Повні й неповні речення. } \\
\text { Просте ускладнене речення. Речення з однорідними } \\
\text { членами. Речення зі звертаннями, вставними словами } \\
\text { (словосполученнями, реченнями). Речення з } \\
\text { відокремленими членами. Повторення в кінці року } \\
\text { відомостей про словосполучення й просте речення }\end{array}$ & $\begin{array}{c}\text { «Давня весна», } \\
\text { «Хотіла б я піснею } \\
\text { стати...», } \\
\text { «Давня казка» }\end{array}$ \\
\hline 9 & $\begin{array}{c}\text { Повторення вивченого у } 8 \text { класі. Синтаксис. } \\
\text { Пунктуація. Пряма й непряма мова. Складне речення, } \\
\text { його ознаки. Складносурядне речення. } \\
\text { Складнопідрядне речення. Безсполучникове речення. } \\
\text { Складне речення з різними видами сполучникового й } \\
\text { безсполучникового зв’язку. Узагальнення й } \\
\text { систематизація вивченого }\end{array}$ & - \\
\hline 10 & $\begin{array}{c}\text { Текст як одиниця спілкування. Етапи підготовки } \\
\text { тексту виступу. Види читання і записування тексту } \\
\text { виступу. Естетика тексту }\end{array}$ & $\begin{array}{c}\text { «Contra spem spero!», } \\
\text { «Мріє, не зрадь», } \\
\text { «Слово, чому ти не } \\
\text { твердая| криця?», } \\
\text { «Стояла я і слухала } \\
\text { весну», «Лісова пісня» }\end{array}$ \\
\hline 11 & $\begin{array}{c}\text { Узагальнення і систематизація найважливіших } \\
\text { відомостей із синтаксису, пунктуації і стилістики }\end{array}$ & - \\
\hline
\end{tabular}

словосполучення від слова й речення. Головне й залежне слово в словосполученні (5 клас).

-Прочитайте виразно вірш Лесі Українки «Як дитиною, бувало» (Леся Українка, 2021, с. 177).

-Визначте тип мовлення. Аргумен- туйте свій вибір.

- Сформулюйте тему й головну думку поезії, використовуючи просте й складне речення відповідно.

-Поміркуйте, чи $є$ словосполученнями конструкції я боюся піддаватись; забувши давню гордість: щуоб не сміятись. 
Обгрунтуйте свою думку.

-3'ясуйте, чи може бути в реченні i словосполученні однакова кількість слів: одне, два, три, чотири, п'ять?

-Випишіть із тексту 5 словосполучень і 5 сполук слів, що не $є$ словосполученням. У словосполученнях позначте головне й залежне слово, спосіб їхнього вираження.

- Творче завдання "Дитинство в асоuุiauฺiяx».

Наведіть власні приклади словосполучень (5-6), що асоціюються з вашим дитинством. Представте асоціативний кущ однокласникам. Складіть невелике висловлення (розповідь, опис чи роздум), використовуючи виписані словосполучення.

\section{Вправа 3.}

Тема. Другорядні члени речення: додаток, означення, обставина (8 клас).

-Прочитайте речення. Визначте вид за наявністю другорядних членів речення. Обгрунтуйте.

Тиша...

Колихає море.

Не колишаться вітрила.

- Поширте речення другорядними членами за власним уподобанням.

- Визначте, яку роль відіграють додані слова.

- Поширте речення другорядними член Тиша- · - ·...

-.- колихає море - - -

Не колишаться - - -... вітрила

- Порівняйте ваші речення 3 авторським варіантом. Який більше до вподоби?

Тиша в морі... ледве-ледве

Колихає море хвилі;

Не колишуться од вітру

На човнах вітрила білі (Леся Українка, 2021, с. 118).

- Знайдіть самостійно і прочитайте виразно вірш повністю.

\section{Вправа 4.}

Тема. Звертання. Непоширені й поширені звертання. Розділові знаки при звертанні (8 клас).

- Прочитайте вірш Лесі Українки «Слово, чому ти не твердая криця?»

- До кого звертається поетеса?

- Як називають такі звертання?

- Випишіть речення зі звертаннями.

Скільки їх?

- Визначте вид звертань (поширене / непоширене), спосіб вираження.

1. Слово, чому ти не твердая криия, Що серед бою так ясно іскриться?

2. Слово, моя ти єдиная зброє, Ми не повинні загинуть обоє!

3. Зброє моя, послужи воякам Краще, ніж служиш ти хворим рукам! (Леся Українка, 2021, с. 166)

-3'ясуйте стилістичну роль звертань у цій поезії. Порівняйте речення зі звертанням і без нього.

\section{Речення зі звертанням}

(із тексту поезії Лесі Українки)

Зброє моя, послужи воякам краще, ніж служиш ти хворим рукам! (Леся

Українка, 2021, с. 166)

\section{Речення без звертання \\ (перебудовані учнями)}

Послужи воякам краще, ніж служиш ти хворим рукам!

Моя зброя послужить воякам краще, ніж служить хворим рукам!

\section{Приклад:}

- Виконайте синтаксичний розбір речення

Слово, моя ти єдиная зброє,

Ми не повинні загинуть обоє! (Леся Українка, 2021, с. 166).

Методичний коментар. Це речення може викликати складнощі у визначенні його виду за будовою. Якщо учень/учениця уважно (правильно) прочитає речення, то визначить слово «зброє» (виділення наше) як частину звертання, а речення як просте ускладнене. Помилково (поспіхом, неуважно) учні читають і записують «зброя». Тоді, відповідно, визначають це 


\begin{tabular}{|c|}
\hline НЕправильно \\
\hline $\begin{array}{l}\text { Слово, моя ти єдиная зброя, } \\
\text { Ми не повинні загинуть обоє! } \\
\text { (складне) }\end{array}$ \\
\hline Правильно \\
\hline $\begin{array}{l}\text { Слово, моя ти єдиная зброє, } \\
\text { Ми не повинні загинуть обоє! } \\
\text { (просте ускладнене) }\end{array}$ \\
\hline
\end{tabular}

Тож учителю варто звернути увагу здобувачів освіти на важливість правильного прочитання речення.

- Творче завдання.

Напишіть невеликий твір про значення слова в житті людини й суспільства як органічне продовження вірша Лесі Українки. Використайте звертання, риторичні питання, спонукальні речення.

\section{Вправа 5}

Тема. Прості ускладнені й неускладнені речення (8 клас)

- Прочитайте вірш Лесі Українки «Contra spem spero!»

- 3'ясуйте, у чому його синтаксичні особливості.

- Чим ускладнені речення поезії?

- Закодуйте речення поезії:

А - ускладнене звертанням; Б ускладнене однорідними членам речення; В - ускладнене відокремленням; Г ускладнене вставним словом;

Д - неускладнене.

Наприклад:

\begin{tabular}{|l|l|}
\hline Гетьте, думи, ви хмари осінні! & 1 А \\
То ж тепера весна золота! & 2 Д \\
Чи то так у жалю, в голосінні & 3 Б \\
Проминуть молодії літа? & \\
(Леся Українка, 2021, с. 74). & \\
\hline
\end{tabular}

-Виконайте синтаксичний розбір речення $з$ кількома ускладнювальними елементами:

I від сліз тих гарячих розтане

Та кора льодовая, міцна,

Може, квіти зійдуть - і настане
Ще й для мене весела весна (Леся Українка, 2021, с. 74).

\section{Вправа 6}

Тема. Види складних речень (узагальнення, 9 / 11 класи)

- Перепишіть речення, поставте необхідні розділові знаки. Визначте тип речення за будовою, його вид.

1. В час гарячий полудневий виглядаю у віконие

ясне небо ясне море ясні хмарки ясне соние.

2. Певно се краӥна світла та злотистої блакиті

певно тут не чули зроду щзо бува негода в світі! (Леся Українка, 2021, с. 118).

-Порівняйте ваш варіант 3 авторським.

-Чи можливі варіанти розділових знаків?

-Від чого це залежить?

-Чи впливають розділові знаки на зміст речення / тексту? Доведіть.

-Чим ускладнені предикативні частини другого речення?

-Випишіть усі безсполучникові речення. Перетворіть їх на сполучникові.

- Визначте вид сполучникових складних речень.

-Поміркуйте, що при цьому зміниться?

\section{Наприклад:}

- Творче завдання «Нарощення».

Виконайте нарощення мовних одиниць за поданим алгоритмом:

Слово - словосполучення - просте речення - складне речення - складна синтаксична конструкція.

Учні працюють за варіантами, в основі яких ключові образи поезії Лесі Українки: I варіант - тиша; II варіант море.

Висновки й перспективи подальших досліджень. Художні тексти Лесі Українки $є$ грунтовним матеріалом для вивчення синтаксису в середній і старшій школі, адже представляють розмаїття всіх синтаксичних одиниць. Проведений лінгводидактичний аналіз програмових творів письменниці розкрив їхні навчальні, 
розвивальні й виховні функції на сучасному уроці української мови.

Запропоновані авторські вправи й системні завдання для вивчення синтаксису в $5,8,9,11$ класах розроблені з урахуванням мети й змісту навчання на основі тексту, передбачають репродуктивну, продуктивну і творчу діяльність здобувачів освіти.

Перспективу подальших наукових досліджень убачаємо в розробленні комплексних вправ і різнорівневих завдань на основі художніх текстів Лесі Українки для вивчення конкретних мовних тем.

\section{ЛIТЕРАТУРА}

1. Глазова О. П. Текстоцентричний підхід у вивченні української мови: методичні рекомендації для вчителів, які працюють у 5 класі / О. П. Глазова [Електронний ресурс]. - Режим доступу: https://cutt.ly/xx3QhwC.

2. Грибан Г. В. Твори Лесі Українки на уроках рідної мови / Г.В. Грибан // Вісник Житомирського державного університету імені Івана Франка. - 2001. - № 7. - С. 35-37.

3. Леся Українка. Повне академічне зібрання творів: у 14 томах. Том 5. Поетичні твори. Ліро-епічні твори / ред. О. Вісич, С. Кочерга. - Луцьк : Волинський національний університет імені Лесі Українки, 2021. - 928 с., 24 с. іл.

4. Лютко I. М. Інтегрований урок з української мови і літературного читання 4 клас: Поезія Лесі Українки на уроках української мови / I. М. Лютко/ [Електронний ресурс]. Режим доступу: https://www.schoollife.org.ua/515-2019.

5. Масицька Т. Є., Мельник I. А. Граматичні особливості ідіостилю Лесі Українки: функції локатива у драмі-феєрії «Лісова пісня» / Т. С. Масицька, І. А. Мельник // Лінгвостилістичні студії. - 2020. - Випуск 12 (Лютий). - C. 130-138. DOI:https://doi. org/10.29038/2413-0923-2020-12-130-138.

6. Нікітіна А. В. Лінгводидактичний аналіз тексту посібника як засіб навчання студентів-філологів / А. В. Нікітіна // Народна освіта. Електронне наукове фахове видання. - 2015. - № 3 [Електронний ресурс]. - Режим доступу: https://cutt.ly/mcwCWsS.

7. Новосельська Н. Т. Виховання любові до краси рідного краю в поезії Лесі Українки (на матеріалах читанок для початкової школи) / Н. Т. Новосельська // Наукові записки Тернопільського національного педагогічного університету імені Володимира Гнатюка. Серія : педагогіка. -2018. - № 1. - C. 33-39. DOI:https://doi.org/10:25128/2415-3605.18.1.5.

8. Пелипась М. I. Характеристика мовних особливостей творчості Івана Франка i Лесі Українки у роздумах Максима Рильського / М. І. Пелипась // Ученые записки Крымского федерального университета имени В. И. Вернадского. Филологические науки. Том 2 (68). - 2017. - № 4. - С. 67-72.

9. Українська література 5-9 класи. Програма для загальноосвітніх навчальних закладів (затверджена Наказом Міністерства освіти і науки України від 07.06.2017 № 804). [Електронний ресурс]. - Режим доступу: https://cutt.ly/txHnXTv.

10. Українська мова 5-9 класи. Програма для загальноосвітніх навчальних закладів (за новим Державним стандартом базової і повної загальної середньої освіти): для загальноосвітніх навчальних закладів з українською мовою навчання [Електронний ресурс]. - Режим доступу: https://cutt.ly/exHRLiD.

11. Фучила О. П. Конспект уроку з української мови: «Власні та загальні іменники. Написання власних іменників з великої букви» / О. П. Фучила. [Електронний ресурс]. Режим доступу: https://cutt.ly/gx0KXES. 


\title{
ИЗУЧЕНИЕ СИНТАКСИСА \\ НА МАТЕРИАЛЕ ТВОРЧЕСТВА ЛЕСИ УКРАИНКИ
}

\author{
Кузнецова Анастасия, \\ старший преподаватель кафедры \\ теории и методики языково-литературного \\ и художественно-эстетического образования \\ Николаевский областной институт \\ последипломного педагогического образования \\ ул. Адмиральская, 4-а, г. Николаев, 54001, Украина \\ anastasiia.kuznietsova@moippo.mk.ua
}

В практико ориентированной статье проанализированы проблемы использования литературного наследия известной украинской писательнииы и общественной деятельницы ХХ века Леси Украинки на современном уроке украинского языка. Определен дидактический потенциал программных произведений писательницы-учебные, развивающие и воспитательные функичии текстов в процессе изучения синтаксиса. Разработаны оригинальные упражнения на основе стихов Леси Украинки во время работы с простым предложением в средней школе. Представлена система заданий по текстоиентрическому подходу для изучения сложного предложения в старшей школе.

Ключевые слова: изучение синтаксиса; лингводидактический анализ текста; поэтические тексты Леси Украинки; простое предложение; сложное предложение; текстоиентризм.

\section{SYNTAX STUDY \\ THROUGH THE CREATIVE WORKS OF LESIA UKRAINKA}

Kuznietsova Anastasiia, Senior Lecturer, the Department of Theory and Methods of Language, Literature, Art and Aesthetic Education

Mykolaiv In-Service Teachers Training Institute 4-a Admiralska Street, Mykolaiv, 54001, Ukraine anastasiia.kuznietsova@moippo.mk.ua

The practice-oriented article analyzes the problem of using the literary heritage of the famous Ukrainian writer, translator, folklorist, and cultural figure of the XX Lesya Ukrainka in a modern lesson of the Ukrainian language. Her contribution to cultural life, in particular literary, is invaluable, because the artist presented various genres of poetry, epic, drama; she developed the genre of dramatic poem in Ukrainian literature.

The didactic potential of the writer's program works, such as teaching, developmental and educational functions of texts in the process of studying syntax, is determined. It was found that the simultaneous study of the syntax and creativity of Lesya Ukrainka is appropriate only in 8th and 10th grades. In other classes, this will encourage teachers to build a Ukrainian language lesson based on the repetition of the studied material or, conversely, to work ahead, thus making interested in the artist's work.

The scientific-methodical article presents different types of exercises based on the literary text. They are analytical (to define the grammatical features of lexical units in the text), constructive (to reconstruct the text or its fragments), creative (to guess the part or create your own text).

Original exercises based on Lesya Ukrainka's poems have been developed during the processing of a simple sentence in secondary school: division of a text into a sentence; sentences 
for the purpose of expression; punctuation marks at the end of the sentence; phrases; main and dependent word in the phrase; secondary members of the sentence; addressing, punctuation marks when addressing; simple compounded and uncompounded sentences. A system of tasks based on a text-centric approach for studying a complex sentence in high school is proposed: types of complex sentences (generalizations).

Keywords: complex sentence; Lesya Ukrainka's poetic texts; linguodidactic analysis of the text; simple sentence; syntax study; text-centrism.

\section{REFERENCES}

1. Fuchyla, O. P. (2015). Konspekt uroku z ukrainskoi movy: «Vlasni ta zahalni imennyky. Napysannia vlasnykh imennykiv z velykoi bukvy» [Summary of the lesson on the Ukrainian language: «Proper and common nouns. Writing proper nouns in capital letters]. [Elektronnyi resurs]. Retrieved from: https://cutt.ly/gx0KXES (ukr).

2. Hlazova, O. P. (2013). Tekstotsentrychnyi pidkhid u vyvchenni ukrainskoi movy: metodychni rekomendatsii dlia vchyteliv, yaki pratsiuiut u 5 klasi [Text-centric approach in the study of the Ukrainian language: guidelines for teachers working in 5th grade]. [Elektronnyi resurs]. Retrieved from: https://cutt.ly/xx3QhwC (ukr).

3. Hryban, H. V. (2001). Tvory Lesi Ukrainky na urokakh ridnoi movy [Works of Lesya Ukrainka in native language lessons]. Visnyk Zhytomyrskoho derzhavnoho universytetu imeni Ivana Franka, 7, 35-37 (ukr).

4. Lesia Ukrainka. (2021). Povne akademichne zibrannia tvoriv: u 14 tomakh. Tom 5. Poetychni tvory. Liro-epichni tvory / red. O. Visych [Complete academic collection of works: in 14 volumes. Volume 5. Poetic works. Lyrical and epic works]. Lutsk: Volynskyi natsionalnyi universytet imeni Lesi Ukrainky, 928 (ukr).

5. Liutko, I. M. (2019). Intehrovanyi urok z ukrainskoi movy i literaturnoho chytannia 4 klas: Poeziia Lesi Ukrainky na urokakh ukrainskoi movy [Integrated lesson on Ukrainian language and literary reading 4th grade: Lesya Ukrainka's poetry in Ukrainian language lessons]. [Elektronnyi resurs]. Retrieved from: https://www.schoollife.org.ua/515-2019 (ukr).

6. Masytska, T. Y. \& Melnyk, I. A. (2020). Hramatychni osoblyvosti ideostyliu Lesi Ukrainky: funktsii lokatyva u drami-feierii «Lisova pisnia [Grammatical features of Lesia Ukrainka's idiosyncrasy: functions of the locative in the drama-extravaganza «Forest Song»]. Linhvostylistychni studii, 12, 130-138. DOI:https://doi.org/10.29038/2413-0923-2020-12-130138 (ukr).

7. Nikitina, A. V. (2015). Linhvodydaktychnyi analiz tekstu posibnyka yak zasib navchannia studentiv-filolohiv [Linguodidactic analysis of the textbook as a means of teaching students of philology]. Narodna osvita, 3 [Elektronnyi resurs]. Retrieved from: https://cutt.ly/ mcwCWsS (ukr).

8. Novoselska, N. T. (2018). Vykhovannia liubovi do krasy ridnoho kraiu v poezii Lesi Ukrainky (na materialakh chytanok dlia pochatkovoi shkoly) [Education of love for the beauty of the native land in the poetry of Lesya Ukrainka (on the materials of textbooks for primary school)]. Naukovi zapysky Ternopilskoho natsionalnoho pedahohichnoho universytetu imeni Volodymyra Hnatiuka. Seriia: pedahohika, 1, 33-39. DOI:https://doi.org/10:25128/24153605.18.1.5 (ukr).

9. Pelypas, M. I. (2017). Kharakterystyka movnykh osoblyvostei tvorchosti Ivana Franka i Lesi Ukrainky u rozdumakh Maksyma [Characteristics of linguistic features of the works of Ivan Franko and Lesia Ukrainka in the reflections of Maksym Rylsky]. Uchenye zapiski Krymskogo federal'nogo universiteta imeni V. I. Vernadskogo. Filologicheskie nauki. Tom, 2, 67-72 (ukr).

10. Ukrainska literatura 5-9 klasy. Prohrama dlia zahalnoosvitnikh navchalnykh zakladiv [Ukrainian literature 5-9 grades. Program for secondary schools (approved by the Order of the 
Ministry of Education and Science of Ukraine from]. (2017). [Elektronnyi resurs]. Retrieved from: https://cutt.ly/txHnXTv (ukr).

11. Ukrainska mova 5-9 klasy. Prohrama dlia zahalnoosvitnikh navchalnykh zakladiv [Ukrainian language 5-9 grades. Program for secondary schools (according to the new State standard of basic and complete general secondary education): for secondary schools with Ukrainian as the language of instruction]. (2017). [Elektronnyi resurs]. Retrieved from: https:// cutt.ly/exHRLiD (ukr). 